\title{
Formation of teachers' readiness for project activity in the context of scientific and methodological work of the Office of international cooperation
}

\author{
Dyagileva O., Leshchenko O., Paziak A., Yurzhenko A.* \\ Kherson State Maritime Academy, Kherson, Ukraine
}

Received: $27.04 .2020 \quad$ Accepted: 24.06 .2020

\begin{abstract}
The article examines the features of the involvement of academic and teaching staff of the higher education institution into the project activities, identifies and analyzes the main directions of the Office of International Cooperation, which contribute to the formation of teachers' readiness for project work. The concept of "project work" in scientific discourse is considered in the paper. It is actualized that the problem of attracting teachers to international activities is of particular importance nowadays. The methods of involvement into the project activity as a form of innovative methodological technologies, with the aim of forming general and professional competences, are described. Particular attention is paid to the theoretical and methodological basis of the research, which is based on competence-based, organizational-innovation and cooperative-activity approaches. The article used theoretical, empirical and statistical methods. It is noted that the Office of International Cooperation deals with the organization of cooperation of higher education institutions with foreign scientific institutions and associations, but first of all involvement of teachers into the project activity. The paper describes the information page of the Kherson State Maritime Academy office on the official site and its main sections, informing teachers about the possibilities of project activities with the foreign partners of the academy. Other engagement methods include the use of social networks, LMS MOODLE e-courses and Zimbra Messenger. It is noted that the use of a gamified approach in the educational process actively motivates future employees of sea and river transport to educational and cognitive activities, allows to form skills of creative thinking and promotes the search for various methods of alternatives. The attention is also focused on the effectiveness of the use of simulation technologies (virtual and mixed reality). Conclusions are made concerning the process of organizing a modernized educational environment and the results of an experimental study on determining the level of readiness for project activities of teachers of Kherson State Maritime Academy.

Key words: LMS MOODLE, social network, professional competence.
\end{abstract}

\section{Формування готовності викладачів до проектної діяльності в контексті науково-методичної роботи відділу міжнародного співробітництва}

\author{
Дягилева О. С., Лещенко О. М., Пазяк А. С., Юрженко А. Ю. \\ Херсонська державна морська академія, Херсон, Україна
}

\begin{abstract}
Анотація. У статті досліджено особливості залучення до участі науково-педагогічних працівників ЗВО до проектної діяльності, визначені та проаналізовані основні напрями відділу міжнародного співробітництва, які сприяють формуванню готовності викладачів до проектної роботи. У роботі розглянуто поняття «проектна діяльність» у науковому дискурсі. Актуалізується, що проблема залучення викладачів до міжнародної діяльності у наш час набуває особливого значення. Описуються методи залучення до участі викладачів 3ВО у проектну діяльність, як одну з форм інноваційних методичних технологій, з метою формування загальних та профресійних компетентностей. Особлива увага акцентується на теоретико-методологічній основі дослідження, яка грунтується на компетентнісному, організаційно-інноваційному та кооперативно-діяльнісному підходах. У статті використовувалися теоретичні, емпіричні та статистичні методи. Зазначається, що відділ міжнародного співробітництва займається організацією співпраці закладу вищої освіти із закордонними науковими установами та асоціаціями, але насамперед - залученням викладачів до проектної діяльності. У роботі описана інформаційна сторінка відділу Херсонської державної морської академії на офіційному сайті та її головні розділи, що інформують викладачів про можливості проектної діяльності з іноземними партнерами академії. До інших методів залучення віднесено також використання соціальних мереж, електронних курсів
\end{abstract}

Corresponding Author: Yurzhenko Alona. Tel. +38(099)901-81-38. E-mail: helen18@online.ua. Kherson State Maritime Academy, Ushakova str., 20, Kherson, Ukraine, 73000.

Відповідальний автор: Юрженко Альона Юріївна.Tel. +38(099)901-81-38. E-mail: helen18@online.ua. Херсонська державна морська академія, пр. Ушакова, 20, Херсон, Україна, 73000. 
LMS MOODLE та Messenger Zimbra. Відзначено, що застосування гейміфікованого підходу в освітньому процесі активно мотивує майбутніх працівників морського та річкового транспорту до навчально-пізнавальної діяльності, дозволяє сформувати навички креативного мислення та сприяє пошуку різноманітних методів альтернативних варіантів. Зосереджено увагу і на ефективності використання симуляційних технологій (віртуальна та змішана реальності). Зроблені висновки щодо процесу організації модернізованого освітнього середовища та результатів експериментального дослідження визначення рівня готовності до проектної діяльності викладачів Херсонської державної морської академії..

Ключові слова: LMS MOODLE, соціальна мережа, професійна компетентність.

\title{
Формирование готовности преподавателей к проектной деятельности в контексте научно-методической работы отдела международного сотрудничества
}

\author{
Дягилева Е. С., Лещенко А. М., Пазяк А. С., Юрженко А. Ю. \\ Херсонская государственная морская академия, Херсон, Украина
}

\begin{abstract}
Аннотация. В статье исследованы особенности привлечения к участию научно-педагогических работников ВУЗ к проектной деятельности, обозначены и проанализированы основные направления отдела международного сотрудничества, способствующие формированию готовности преподавателей к проектной работе. В работе рассмотрено понятие «проектная деятельность» в научном дискурсе. Актуализируется, что проблема привлечения преподавателей к международной деятельности в наше время приобретает особое значение. Описываются методы привлечения преподавателей ВУЗов к участию в проектной деятельности, как одной из форм инновационных методических технологий с целью формирования общих и профессиональных компетентностей. Особое внимание акцентируется на теоретико-методологической основе исследования, основанной на компетентностном, организационно-инновационном и кооперативнодеятельностном подходах. В статье использовались теоретические, эмпирические и статистические методы. Отмечается, что отдел международного сотрудничества занимается организацией сотрудничества ВУЗа с зарубежными научными учреждениями и ассоциациями, но прежде всего - привлечением преподавателей к проектной деятельности. В работе описана информационная страница отдела Херсонской государственной морской академии на официальном сайте и ее главные разделы, информирующие преподавателей о возможности проектной деятельности с иностранными партнерами академии. К другим методам привлечения отнесены также использование социальных сетей, электронных курсов LMS MOODLE и Messenger Zimbra. Отмечено, что применение геймифицированного подхода в образовательном процессе активно мотивирует будущих работников морского и речного транспорта в учебно-познавательной деятельности, позволяет сформировать навыки креативного мышления и способствует поиску различных методов альтернативных вариантов. Сосредоточено внимание и на эффективности использования симуляционных технологий (виртуальная и смешанная реальности). Сделаны выводы о процессе организации модернизированной образовательной среды и результатах экспериментального исследования определения уровня готовности к проектной деятельности преподавателей Херсонской государственной морской академии.
\end{abstract}

Ключевые слова: LMS MOODLE, социальная сеть, профессиональная компетентность.

\section{Bcmyn}

Міжнародне співробітництво у наш час $є$ одним із пріоритетних напрямів діяльності закладу вищої освіти (3ВО) з метою його інтеграції у загальносвітову спільноту, створення умов для підвищення якості вищої освіти, ефективності наукових досліджень, а також забезпечення конкурентоспроможності на вітчизняному ринку освітніх послуг.

Сьогодні в Україні існує потреба у фахівцях та науковцях, які не лише володіють теоретичними знаннями, а й отримали міжнародний практичний досвід.

Проблема формування готовності викладачів до проектної діяльності - це підготовка фрахівця в галузі освіти, здатного виконувати професійні завдання за допомогою використання новітніх інформаційних технологій (інформаційно-комунікативного педагогічного середовища, гейміфікованого підходу, системи змішаного навчання, технологій віртуальної/доповненої/змішаної реальності, технології використання перевернутого класу, Інтернету речей, адаптованого тестування тощо). Отже, постала проблема формування професійної компетентності викладачів до проектної діяльності, що обумовлюється обґрунтуванням та реалізацією певних педагогічних умов. 
Проблема проектної діяльності викладачів не $є$ новою у педагогічній теорії та практиці, але переосмислення і застосування її у нинішній ситуації дає змогу говорити нам як про сучасну освітню технологію. Розв'язання даної проблеми полягає у наявності суперечності між традиційним розумінням навчального процесу та проблемою створення оптимальних умов для формування та розвитку у викладачів не лише предметних компетентностей, а й методичних, зокрема формування готовності до стимулювання проектної науково-технічної творчості, що спрямовує діяльність викладачів ЗВО до пошуків нових методичних підходів, методів та засобів навчання, їх ефективної реалізації.

Останнім часом все більше з'являється наукових робіт, присвячених використанню методу проектів в навчальному процесі закладів середньої, професійно-технічної освіти, проте проблему проектної діяльності викладачів в організації навчального процесу у системі вищої освіти досліджено недостатньо.

Теоретичне обірунтування ідеї проектної діяльності розроблено зарубіжними (Д. Дьюї, У. Кілпатрик, Є. Коллінгс, А. Стівенсон, Р. Стімсон та ін.) та вітчизняними (О. Кайдановська, А. Кіктенко, О. Любарська, Н. Матяш, О. Пєхота, Є. Полат, В. Радіонова, С. Сисоєва, В. Слободченкова, І. Шендрик та ін.) дослідниками. Вперше детально описали метод проектів Д. Дьюї та У. Кілпатрик, назвавши метод «інструментальною педагогікою».

На думку багатьох дослідників поняття «метод проектів», «проектна діяльність» та «проектна технологія» однакові, один із способів з проектування власного дослідження. Так, наприклад, дослідник Л. Єленич у своїй статті виокремила наступні точки зору вчених щодо категоріальних ознак поняття «проектна діяльність»: систематична форма організації діяльності у взаємозв'язку ії теоретичних і практичних аспектів (С. Кримський); інноваційна форма організації освітнього середовища, в основі якої лежить комплексний характер діяльності тимчасового колективу спеціалістів в умовах активної взаємодії з навколишнім середовищем (Л. Ващенко); комплекс пошукових, дослідницьких, графрічних та інших видів робіт, що виконуються з метою практичного чи теоретичного розв'язання значущої проблеми (Є. Полат) та ін. Як бачимо, кожна з цих думок має свої характерні особливості, але кожна 3 них спрямована на майбутнє та є прогнозованою [1, с.162].

Різні аспекти проектування розглядають у своїх роботах К. Приходченко, А. Цимбалару, О.Ярошинська та ін., а дослідження особливостей проектувальної функції педагогічної діяльності здійснювали В. Монахов, В. Сластьонін та ін. Проблемі використання проектних технологій у освітньому процесі присвятили свої праці В. Гузєєв, І. Єрмаков, Є. Полат, Г. Селевко та ін.

Суть процесу проектної діяльності, технології та найголовніше, умови її впровадження в навчальний процес відображено у дослідницьких роботах О. Коберник, І. Коновальчук, Т. Подобедової. Зміст і значення проектної діяльності розглянуто у публікаціях А. Вдовиченко, А. Терещука, Л. Хоменко. Застосування проектної діяльності в навчально-виховному процесі $\epsilon$ предметом дослідження й інших науковців, зокрема Р. Вендровскої, А. Коробової, І. Ляхова.

Актуальні проблеми організації проектної діяльності стали предметом дисертаційних досліджень таких дослідників: С. Ізбаш «Проектна діяльність як фактор соціально-професійної адаптації студентів педагогічного університету» (теоретично обірунтовано та експериментально перевірено ефективність моделі соціально-професійної адаптації студентів засобами проектної діяльності) [2], О. Зосименко «Організація проектної діяльності майбутніх педагогів у процесі вивчення педагогічних дисциплін» (з'ясовано можливості проектної діяльності у контексті педагогічної підготовки) [3], В. Каламаж «Психологічні чинники ефективності групової проектної діяльності студентів 3ВО у процесі вивчення іноземної мови» (уточнено зміст поняття групової проектної діяльності студентів у процесі вивчення іноземної мови спрямовану на вирішення певної проектної задачі й створення реального продукту за фасилітативної допомоги викладача) [4].

Meта нашого дослідження - опис методів залучення до участі викладачів 3ВО у проектну діяльність, як одну із фрорм інноваційних методичних технологій, з метою фрормування загальних та професійних компетентностей в контексті науково-методичної роботи відділу міжнародного співробітництва. 


\section{II Матеріал і методи дослідження}

Теоретико-методологічна основа дослідження ґрунтується: на компетентнісному підході, який визначає проектні уміння як компоненту фахової компетентності викладача; на організаційноінноваційному підході, що передбачає усвідомлення викладачем інноваційних процесів організації проектної діяльності відповідно до специфріки освітнього процесу Херсонської державної морської академії (ХДМА); на кооперативно-діяльнісному підході, який визначає основні аспекти методичного супроводу формування проектних умінь та навичок викладачів 3ВО.

У нашому дослідженні було використано такі взаємопов'язані методи, як теоретичні (понятійнотермінологічний, моделювання), емпіричні (пряме та опосередковане спостереження, анкетування, проектування) та статистичні (методи математичної статистики).

Теоретичні методи використовувалися для визначення основних термінів дослідження «проектна діяльність», «метод проектів» та «проектна технологія», аналіз та узагальнення цих понять 3 позиції різних наукових підходів.

Метод моделювання використовувався з метою визначення методологічних підходів, шляхів та засобів організації проектної діяльності викладачів.

Емпіричні методи було використано для перевірки ефективності запропонованої методики формування готовності викладачів до проектної діяльності.

Статистичні методи застосовано задля статистичної та аналітичної обробки даних з метою якісного та кількісного аналізу результатів дослідження.

\section{III Результати}

Відділ міжнародного співробітництва ХДМА займається організацією співпраці академії із закордонними 3ВО, науковими установами та асоціаціями, вченими, викладачами та посадовими особами; підготовкою пропозицій щодо налагодження контактів із закордонними закладами освіти, агенціями, асоціаціями, а також їх представництвами в Україні; пошуком інформації щодо міжнародних грантів, проектів, міжнародних наукових конференцій та програм підтримки науково-освітньої діяльності викладачів, співробітників, здобувачів вищої освіти; організацією мобільності професорськовикладацького складу та здобувачів вищої освіти; вивченням та узагальненням досвіду розробки міжнародних навчальних програм у галузі морської освіти і науки, вивчення доцільності та можливостей їх реалізації в умовах ХДМА.

3 метою покращення якості надання освітніх послуг, поглиблення науково-дослідної роботи, залучення до проектної діяльності наукових, науково-педагогічних, педагогічних працівників та здобувачів вищої освіти відділом міжнародного співробітництва на сайті ХДМА було створено інформаційну сторінку, яка висвітлює загальні положення та завдання відділу. Результати моніторингу інформації щодо міжнародних наукових конференцій, стажувань, виставок та конкурсів відображені у відповідних електронних каталогах, які щоденно оновлюються на сайті (див. за посиланням http://kma.ks.ua/ua/ob-akademii/viddil-z-mizhnarodnikh-zv-yazkiv).

Відділом міжнародного співробітництва також розроблено електронний каталог наукових журналів, які включено до міжнародних наукометричних баз даних Web of Science та Scopus, що за тематикою відповідають напрямкам діяльності Херсонської державної морської академії. Окремим розділом інформаційної сторінки відділу є вкладка «Партнери», яка містить список закордонних ЗВО (у кільк. 15) та посилання на їх офіційні веб-сторінки. За допомогою зручного інтерфейсу з легкістю можна ознайомитись з інформацією про партнерів, в міжнародних проектах яких можна взяти участь.

Створено Telegram-канал (див. за посиланням https://t.me/International_affairs_KSMA) 3 метою щоденного інформування викладачів, співробітників, здобувачів вищої освіти про міжнародні конференції, стажування, проведення яких заплановано організаторами в поточному навчальному році та своєчасного нагадування підписникам про наближення дедлайну у різних програмах міжнародної кредитної мобільності. 
ISSN 2307-9770. Engineering and Educational Technologies, 2020, 8 (2), 92-101. CC-BY @ KrNU, EETECS, Dyagileva O., Leshchenko O., Paziak A., Yurzhenko A., 2020

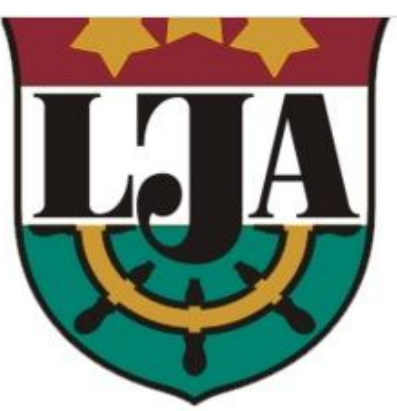

Латвійська морська академія

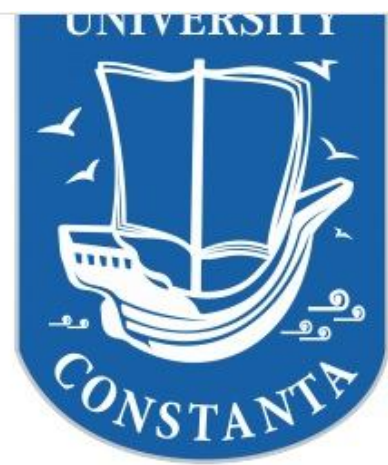

Морський університет Констанци

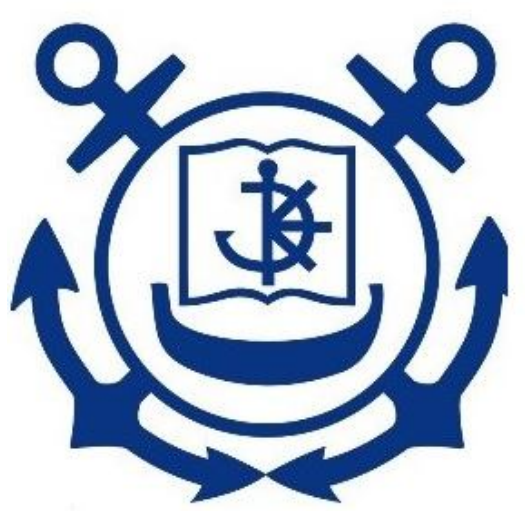

Литовська морська академія

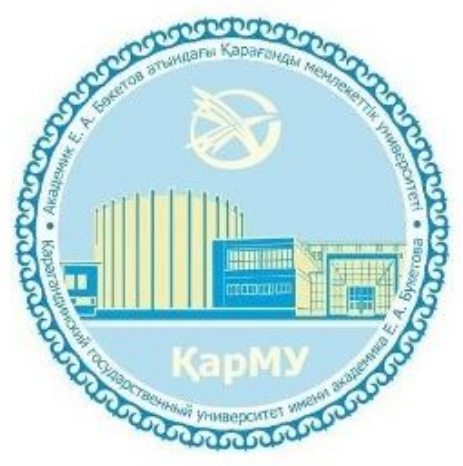

Карагандинський державний університет

\begin{tabular}{l} 
видавнитво \\
\hline наиі партнери \\
\hline
\end{tabular}

Відділ міжнародного співроб̈ітництва -

\begin{tabular}{|l|}
\hline Cпівробітоики \\
\hline Запроитумо до участі \\
\hline Партиери \\
\hline Рейтинги \\
\hline
\end{tabular}

Міжнародний морсъкий кластер «IIarama IT-OIM:

Комунікатиений підхіә

Контактна інформація ХДМА

Taлepea

Рис. 1. Перелік посилань на офріційні сайти партнерів ХДМА у розділі відділу міжнародного співробітництва на офріційному сайті академії

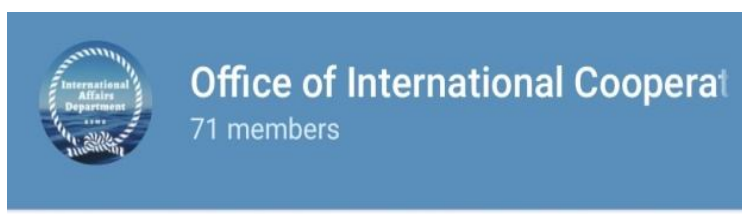

Info

Група займається поширенням інформації про можливості викладацької мобільності та здобувачів вищої освіти. Співпраця із закладами вищої освіти та науковими установами зарубіжжя.

t.me/International_affairs_KSMA

Invite Link

Notifications

On

\section{$+\stackrel{\circ}{\text { Add Member }}$}

Рис. 2. ПрофрільTelegram-каналу відділу міжнародного співробітництва

Так, для залучення викладачів до проектної діяльності у 2020 р. відділом також було реалізовано на платформі LMS Moodle електронний курс «Міжнародна діяльність ХДМА». Розроблено рекомендації щодо збору необхідної документації, порядок офрормлення відряджень для здійснення міжнародної 
кредитної мобільності та анкету для оцінки потенціалу кредитної мобільності наукових, науковопедагогічних, педагогічних працівників, яку проходять усі, хто записаний на курс. Одним із вагомих критеріїв успіху сучасних університетів $є$ включення до міжнародних рейтингів. Упродовж 2020 року відділ міжнародного співробітництва здійснював аналіз та подачу статистичних даних для участі у міжнародних рейтингах, серед них - uniRank, Times Higher Education, THE World University Rankings та iH.

Керівником відділу міжнародного співробітництва надаються рекомендації щодо використання в освітньому процесі мультимедійних панелей, елементів доповненої та віртуальної реальності. У курсі розглядається програмне забезпечення, що допомагає викладачам створювати інтерактивні лекції, семінари лабораторні та практичні заняття, щоб розуміти наскільки це впливає на успішність та чи готові самі викладачі використовувати інноваційні технології в роботі. Практика свідчить, що електронний курс для викладачів формує у них прагнення до постійного розвитку та удосконалення знань, умінь та навичок.

Слід відзначити, що учасники міжнародної кредитної мобільності ХДМА успішно проходять стажування у закордонних ЗВО та діляться власним досвідом зі своїми колегами. 2019 навчальний рік був насиченим успішними стажуваннями для викладачів кафедри англійської мови в судноводінні, які мали змогу опанувати новітні методи навчання, набути досвіду впровадження сучасних освітніх стратегій. Так, викладачі ХДМА пройшли стажування на базі університету «Collegium Civitas» у м. Варшава (Польща), в одному з провідних закладів на ринку освіти, що вирізняється практичним підходом до навчання. Вдало опанували програму Центру польської освіти «Інтернаціоналізація вищої освіти. Організація освітнього процесу та інноваційні методи навчання у закладах вищої освіти Польщі». За результатами стажування викладачі ХДМА підготували проект «Providing Learning Environment to International Student's as the Maritime Institution» та презентували його під час виїзного модуля.

Moodle KSMA українська (uk) -

\section{Міжнародна діяльність ХДМА}

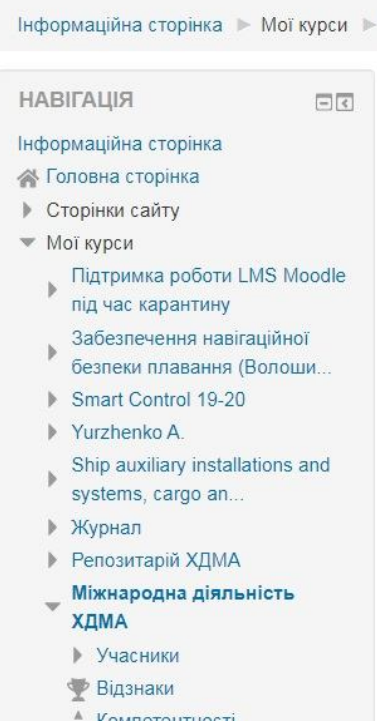

Приєднуйтесь до нас!
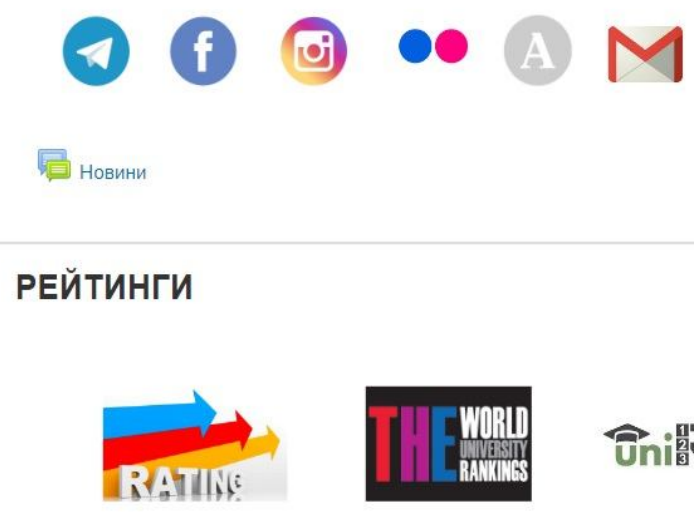

Uิni: $\mathrm{IR}_{\text {Rank }}$

Рис. 3. Електронний курс «Міжнародна діяльність ХДМА» у LMS Moodle

Співробітники відділу активно використовують корпоративну почту Zimbra, яка дозволяє ставити завдання, використовуючи при цьому календар, а портфель (хмарне сховище) створює можливість для зберігання важливих для проектів документи і надавати всім доступ.

Розроблене за допомогою сервісу Google анкетування підтверджує важливість та позитивний вплив окреслених у статті методів формування готовності викладачів до проектної роботи. 367 викладачів, які прийняли участь у опитуванні, більшість (59 осіб) обрали відповідь «Підтримую роботу відділу» в анкеті. 


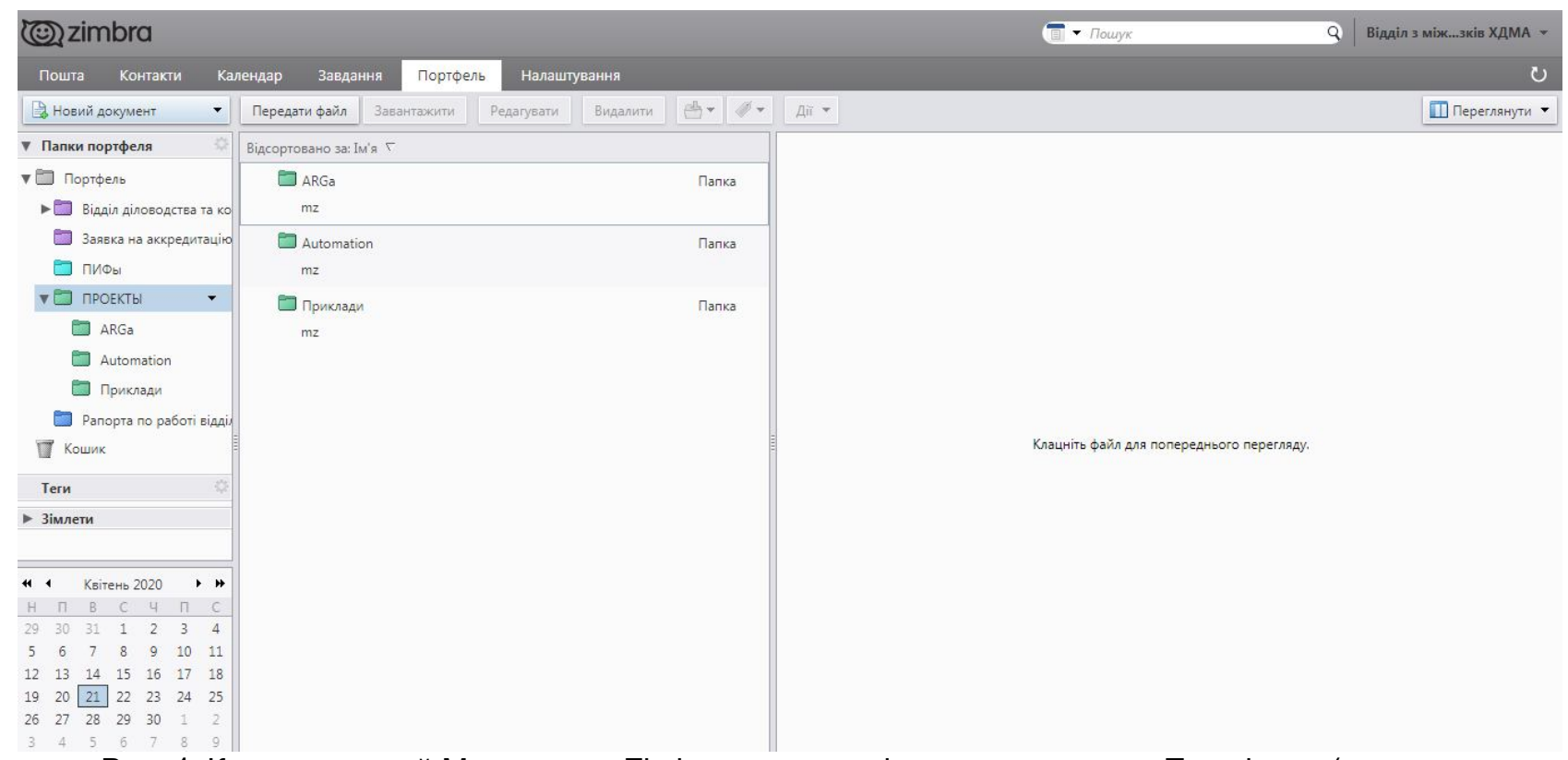

Рис. 4. Корпоративний Messenger «Zimbra» з можливістю використання Портфелю (хмарного хранилища), в якому розташовані необхідні для проектів документи

\section{IV Обговорення}

Аналіз дослідження проектної діяльності викладачів дозволив виявити, що у всьому світі широко використовуються інноваційні технології у формуванні готовності викладачів до роботи у проектній діяльності, що у свою чергу дозволяє удосконалити процес їх фахової підготовки та забезпечує підвищення професійної компетентності. Ми поділяємо думку з дослідниками О. Жерновниковою, Л. Перетягою, А. Ковтун та ін., що одним із чинників, який сприяє ефективному розвитку освітнього процесу сучасного закладу вищої освіти, $є$ формування цифрової компетентності засобами гейміфікації, оскільки в освіті переважає нова ідеологія, заснована на «гейміфікації», де на зміну традиційним педагогам приходять «координатори онлайн-платфрорм і освітніх траєкторій». Цілком правильною $є$ технологія формування цифррової компетентності засобами гейміфікації, яку реалізовано на таких етапах: професійно-мотиваційний, змістово-діяльнісний, рефрлексійно-корегувальний [5].

Так, наприклад, у дослідженні з гейміфікації відзначається, що електронні курси LMS MOODLE мають потенційну освітню можливість як ефективний засіб для формування професійної компетентності, а інтерактивні вправи наближають до живого спілкування за відсутності природного мовного оточення і можуть бути використані як частина системи формування іноземної професійної компетентності майбутніх морських спеціалістів. Саме Форум забезпечує двосторонній зв'язок викладача зі здобувачами вищої освіти між собою. У курсі розроблені викладачем наявні деякі елементи гейміфікації (відзнаки, ігри, приховані елементи, таблиця лідерів тощо), тобто навчальний контент подається з використанням гейміфікованих елементів, що значно підвищує мотивацію здобувачів вищої освіти до навчання [6]. Іншою новітньою технологією, що допомагає формувати профресійну компетентність морського фрахівця $€$ симуляційні технології (віртуальна та змішана реальності). Дослідниця Г. Попова доводить ефективність використання даних технологій для покращення рівня підготовки майбутніх фахівців та підвищення їх рівня професійної підготовки $[7,8]$. Ми також поділяємо думку, що така новітні технологія, як доповнена реальність, може бути використана у багатьох напрямках освіти, зокрема у підвищенні кваліфікації викладачів [9, 10]. Отже, цифрова компетентність, як здобувача вищої освіти, так і викладача, має важлива значення для досягнення успіху. Викладачам потрібно підвищувати кваліфікацію, приймати участь у проектній діяльності та підвищувати рівень своєї цифрової грамотності [11-14]. 


\section{V Висновки}

Отже, науково-методичну роботу відділу міжнародного співробітництва проектну діяльність можна розглядати як освітню технологію, завдяки якій викладачі та здобувачі вищої освіти залучаються до навчального процесу Херсонської державної морської академії та самостійно формулюють навчальні проблеми, шукають шляхи розв'язання та коригують свою діяльність задля досягнення необхідного результату. У результаті теоретичного аналізу наукової літератури уточнено сутність і взаємозв'язок базових понять дослідження «проектна діяльність» та «метод проекту».

Безумовно, для організації модернізованого освітнього середовища викладачам треба оволодіти необхідними інформаційними навичками, поєднувати традиційне навчання з інтерактивним (створювати змішані курси, застосовувати технології використання перевернутого класу, Інтернету речей, адаптованого тестування тощо), здійснювати міжнародне наукове співробітництво. Аналіз практики реалізації комплексу запропонованих педагогічних умов та методів свідчить про позитивний результат рівня готовності до проектної діяльності викладачів ХДМА. Проведене дослідження, звісно, не вичерпує всіх аспектів проблеми формування готовності викладачів до проектної діяльності в контексті науковометодичної роботи відділу міжнародного співробітництва. Оскільки методика навчання постійно розвивається разом із тим, як змінюються інформаційні технології, до перспектив майбутніх досліджень ми відносимо аналіз використання інших методів, зокрема вебінарів та майстер класів, для залучення викладачів та здобувачів вищої освіти до міжнародної проектної діяльності.

\section{Бібліографічні посилання}

1. Єленич Л. С. Проектна екологічна діяльність в системі професійної підготовки майбутніх учителів біології / Освіта дорослих: теорія, досвід, перспективи, 2012. Вип. 5. С. 160-164.

2. Ізбаш С. С. Проектна діяльність як фрактор соціально-профессійної адаптації студентів педагогічного університету: дис... канд. пед. наук: 13.00.04 / Центр. ін-т післядиплом. пед. освіти АПН України. К., 2007. 204 с.

3. Зосименко О. В. Організація проектної діяльності майбутніх педагогів у процесі вивчення педагогічних дисциплін: дис... канд. пед. наук: 13.00.04 / Полтавський держ. пед. ун-т ім. В. Г. Короленка. Полтава., 2010. 256 с.

4. Каламаж В. О. Психологічні чинники ефективності групової проектної діяльності студентів 3 ВО у процесі вивчення іноземної мови: дис... канд. психол. наук: 19.00.01 / Східноєвроп. нац. ун-т ім. Лесі Українки. Луцьк., 2019. 225 с.

5. Жерновникова О. А, Перетяга Л. Є, Ковтун А. В., Кордубан М. В, Наливайко О. О., Наливайко Н. А.Технологія формування цифрової компетентності майбутніх учителів засобами гейміфікації / Інформаційні технології і засоби навчання. Харків., 2020.Том 75, № 1. С. 170-185.

6. Юрженко А. Електронний курс на LMS MOODLE для викладання «Морської англійської мови за професійним спрямуванням». Інформаційні технологій та засоби навчання. 2019. Вип. 71, №3. С.92-101.

7. Попова Г. В., Юрженко А. Ю. Репозитарій компетентностей як інструмент оцінки професійної компетентності майбутніх моряків. IKT в освіті, дослідженнях та індустріальних додатках (ICTERI, 2019): матеріали XV міжнар. наук.-практ. конф., Ч. II, м. Херсон, 2019. C.425-429. URL: http://ceur-ws.org/Vol-2387/20190409.pdf. (дата звернення 24.04.2020).

8. Львов М., Попова Г. Використання симуляційних технологій віртуальної реальності у підготовці майбутніх судноводіїв: матеріали II міжнародного семінару з використання доповненої реальності в освіті. 2019. URL: http://ceur-ws.org/Vol2547/paper04.pdf (дата звернення 24.04.2020).

9. Почтовюк С., Вакалюк Т., Пікілняк А. Можливості використання доповненої реальності у різних напрямках навчання: матеріали II міжнародного семінару з використання доповненої реальності в освіті. 2019. URL: http://www.ceurws.org/Vol-2547/paper07.pdf (дата звернення 24.04.2020).

10. Шишкіна М., Маріенко М. Доповнена реальність як інструмент відкритої наукової платформи з дослідницької співпраці у віртуальних командах: матеріали II міжнародного семінару з використання доповненої реальності в освіті. 2019. URL: http://www.ceur-ws.org/Vol-2547/paper08.pdf (дата звернення 24.04.2020).

11. Кузьминська О., Мазорчук М., Морзе Н., Павленко В., Прохоров А. Цифрова компетентність учнів та викладачів в Україні: вимірювання, аналіз, перспективи розвитку: матеріали 14-ї міжнародної конференції з питань IKT в галузі освіти, досліджень та промислових застосувань. Інтеграція, гармонізація та передача знань. 2018. URL: http://ceurws.org/Vol-2104/paper_169.pdf (дата звернення 24.04.2020).

12. Федоренко Е., Величко В., Стопкін А., Чорна А., Соловьов В. Інформатизація освіти як запорука існування та розвитку сучасної вищої освіти: матеріали 6-го семінару з питань хмарних технологій в освіті. 2018. URL: http://ceur-ws.org/Vol2433/paper01.pdf (дата звернення 24.04.2020).

13. Балик Н., Барна О., Шмигер Г., Олексюк В. Модель професійної перепідготовки вчителів на основі розвитку компетентностей STEM: матеріали 14-й Міжнародної конференції з питань IKT в галузі освіти, досліджень та промислових застосувань. Інтеграція, гармонізація та передача знань. 2018. URL: http://ceur-ws.org/Vol2104/paper_157.pdf (дата звернення 24.04.2020). 
14. Пайєнко Т., Федосов В. Чи можуть інформаційні технології підвищити ефективність уряду: матеріали 15-ої Міжнародної конференції з питань IKT в галузі освіти, досліджень та промислових застосувань. Інтеграція, гармонізація та передача знань. 2019. URL: http://ceur-ws.org/Vol-2393/paper_315.pdf (дата звернення 24.04.2020).

\section{References}

1. Yelenych, L. (2012). Project environmental activity in the system of vocational training of future biology teachers. Adult Education: Theory, Experience, Prospects, (5), 160-164. [in Ukrainian]

2. Izbash, S.S. (2007). Project activity as a factor of socio-professional adaptation of the students of the pedagogical university (dissertation). K., Ukraine, 204. [in Ukrainian]

3. Zosymenko, O.V. (2010). Organization of the project activity of future teachers in the process of studying pedagogical disciplines (dissertation). Poltava, Ukraine, 256. [in Ukrainian]

4. Kalamazh, V.O. (2019). Psychological factors of effectiveness of group project activity of students of Zvo in the process of learning a foreign language (dissertation). Lutsk, Ukraine, 225. [in Ukrainian]

5. Zhernovnykova, O.A., Peretyaga, L.E., Kovtun, A.V., Korduban, M.V., Nalyvaiko, O.O., Nalyvaiko, N.A. (2020). Technology of digital competence formation of future teachers by means of gamification. Information Technologies and Learning Tools, 75, 170-185. URL: https://www.researchgate.net/ publication/ 339589857_ TEHNOLOGIA_FORMUVANNA_CIFROVOI_ KOMPETENTNOSTI_MAJBUTNIH_UCITELIV_ZASOBAMI_GEJMIFIKACII (accessed 24.04.2020). [in Ukrainian]

6. Yurzhenko, A. (2019). An e-course based on the LMS MOODLE to teach "Maritime English for professional purpose". Information Technologies and Learning Tools, 71, 92-101. doi: https://doi.org/10.33407/itlt.v71i3.2512.

7. Popova, H., Yurzhenko, A. (2019). Competency framework as an instrument to assess professional competency of future seafarers. In Proceedings of the 15th International Conference on ICT in Education, Research and Industrial Applications. Integration, Harmonization and Knowledge Transfer (ICTERI, 2019) (Vol. II, pp. 425-429). Kherson, Ukraine: CEUR Workshop Proceedings. URL: http://ceur-ws.org/Vol-2387/20190409.pdf (accessed 24.04.2020).

8. Lvov, M., Popova, H. (2019). Simulation technologies of virtual reality usage in the training of future ship navigators. In $2 n d$ International Workshop on Augmented Reality in Education. URL: http://ceur-ws.org/Vol-2547/paper04.pdf (accessed 24.04.2020).

9. Pochtoviuk, S.I., Vakaliuk, T.A., Pikilnyak, A.V. (2019). Possibilities of application of augmented reality in different branches of education. In 2nd International Workshop on Augmented Reality in Education. URL: http://www.ceur-ws.org/Vol2547/paper07.pdf (accessed 24.04.2020).

10. Shyshkina, M., Marienko, M. (2019). Augmented reality as a tool for open science platform by research collaboration in virtual teams. In 2nd International Workshop on Augmented Reality in Education. URL: http://www.ceur-ws.org/Vol-2547/paper08.pdf (accessed 24.04.2020).

11. Kuzminska, O., Mazorchuk, M., Morze, N., Pavlenko, V., Prokhorov, A. (2018). Digital Competency of the Students and Teachers in Ukraine: Measurement, Analysis, Development Prospects. In 14th International Conference on ICT in Education, Research and Industrial Applications. Integration, Harmonization and Knowledge Transfer. URL: http://ceur-ws.org/Vol2104/paper_169.pdf (accessed 24.04.2020).

12. Fedorenko, E., Velychko, V., Stopkin, A., Chorna, A., Soloviev, V. (2018). Informatization of education as a pledge of the existence and development of a modern higher education. In 6th Workshop on Cloud Technologies in Education. URL: http://ceur-ws.org/Vol-2433/paper01.pdf (accessed 24.04.2020).

13. Balyk, N., Barna, O., Shmyger, G., Oleksiuk, V. (2018). Model of Professional Retraining of Teachers Based on the Development of STEM Competencies In 14th International Conference on ICT in Education, Research and Industrial Applications. Integration, Harmonization and Knowledge Transfer. URL: http://ceur-ws.org/Vol-2104/paper_157.pdf (accessed 24.04.2020).

14. Paientko, T., Fedosov, V. (2019). Can Information Technology Increase Government Effectiveness? In 15th International Conference on ICT in Education, Research and Industrial Applications. Integration, Harmonization and Knowledge Transfer. URL: http://ceur-ws.org/Vol-2393/paper_315.pdf (accessed 24.04.2020).

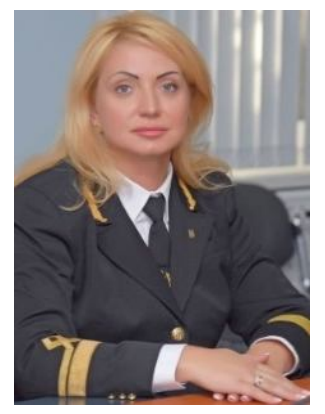

Дягилева Олена Сергіївна,

К.п.н., проректор з навчально-методичної роботи,

Херсонська державна морська академія,

пр. Ушакова 20, м. Херсон

Тел. +380552496174. E-mail: ksma@ksma.ks.ua

\section{Diagileva Olena Sergiivna,}

$\mathrm{PhD}$ in Educational Sciences, Vice-Rector on Academic Work of Kherson State Maritime Academy

Kherson State Maritime Academy,

20 Ushakova str., Kherson

Tel. +380552496174. E-mail: ksma@ksma.ks.ua

ORCID:https://orcid.org/0000-0003-3741-4066 


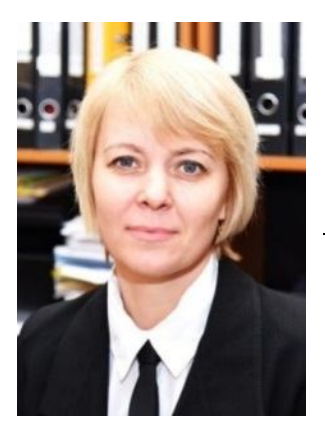

\section{Лещенко Альона Михайлівна}

Профеесор, директор Наукового парку ХДМА "Інновації морської індустрії»

Херсонська державна морська академія,

пр. Ушакова 20, м. Херсон

Тел. +380505540008. E-mail: alena020114@ukr.net

\section{Leshchenko Alena Mykhailivna}

Professor, Director of the Science Park of the Kherson State Marine Academy "Innovations in the marine industry"

Kherson State Maritime Academy,

20 Ushakova str., Kherson

Tel.+380505540008. E-mail: alena020114@ukr.net

ORCID: https://orcid.org/0000-0002-6586-2926

Researcher ID: G-1105-2019

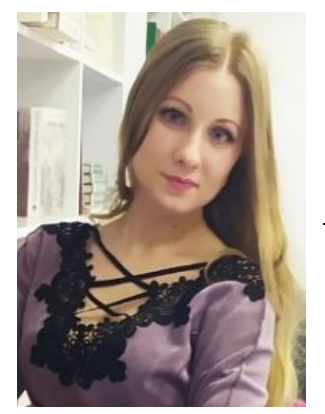

Пазяк Алла Сергіївна,

фахівець відділу міжнародного співробітництва,

Херсонська державна морська академія,

пр. Ушакова 20, м. Херсон

Тел. +380678651242. E-mail: pazyakalla@gmail.com

\section{Paziak Alla Sergiivna,}

Specialist of the Office of International Cooperation

Kherson State Maritime Academy,

20 Ushakova str., Kherson

Tel. +380678651242. E-mail: pazyakalla@gmail.com

ORCID: https://orcid.org/0000-0002-7699-6428

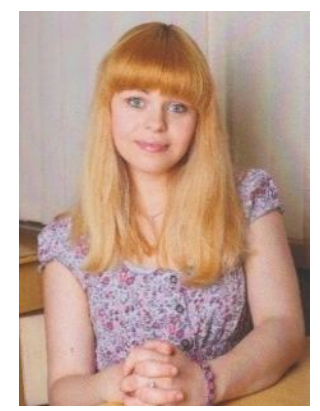

Юрженко Альона Юріївна,

Начальник відділу міжнародного співробітництва,

Херсонська державна морська академія,

пр. Ушакова 20, м. Херсон

Тел. +380999018138. E-mail: helen18@online.ua

Yurzhenko Alona Yuriivna,

Head of Office of International Cooperation,

Kherson State Maritime Academy,

20 Ushakova str., Kherson

Tel. +380999018138. E-mail: helen18@online.ua

ORCID: https://orcid.org/0000-0002-6560-4601

Researcher ID: F-9241-2019

\section{Citation (APA):}

Dyagileve, O., Leshchenko, O., Paziak, A., Yurzhenko, A. (2020). Formation of teachers' readiness for project activity in the context of scientific and methodological work of the Office of international cooperation. Engineering and Educational Technologies, 8 (2), 92 101. doi: https://doi.org/10.30929/2307-9770.2020.08.02.08

\section{Цитування (ДСТУ 8302:2015):}

Дягилева О. С., Лещенко О. М., Пазяк А. С., Юрженко А. Ю. Формування готовності викладачів до проектної діяльності в контексті науково-методичної роботи відділу міжнародного співробітництва / Інженерні та освітні технології. 2020. Т. 8. № 2. C. 92-101. doi: https://doi.org/10.30929/2307-9770.2020.08.02.08

Обсяг статmі: $\quad$ сторінок-10 ; умовних друк. аркушів - 1,448. 